\title{
Evaluation Program of Garbage Bank as Development Efforts of Society on Garbage Management in Jepara, Central Java
}

\begin{abstract}
Anita Dyah Asmaranti ${ }^{1}$
Abstract. This study entitled: "Evaluation Of Garbage Bank As Development Effort of Society On Garbage Management In Jepara, Central Java". This study intends to evaluate the implementation of the Garbage Bank program and find out how the community participation and the obstacles in implementing the Garbage Bank program. This study uses qualitative research design methods and approaches Inductive Descriptif. Informants consisted of elements: Local Government, Community and Garbage Bank managers in each group. For the purposes of data analysis, the author uses the theory of evaluation with CIPP evaluation method whereby elements analyzed consisted of: content, Input, Process and Product and normative rules related to the object and the subject studied. Based on the results of data processing and analysis we concluded that the Garbage Bank implemented in Jepara has been running quite well but is still in the stage of education in which the targets are achieved is to introduce the public to the program so that the program later to become a forum for community empowerment. Community participation has been good enough, but of course there are still many shortcomings that need to be improved, among other things: lack of infrastructure, limited human resources, lack of socialization, limited funds and limited garbage recycling product market. The solution is, of assistance to the Garbage Bank community, training and socialization, open markets products through exhibitions.

Keywords: Evaluation; Empowerment; Garbage Bank.
\end{abstract}

\section{Introduction}

Act No. 23 of 2014 on Regional Government, issued by the Government in lieu of Act No. 32 of 2004 on Regional Government has set concerning government affairs, namely the power of government under the authority of the President that the implementation is done by the Ministry of state and administrators of the region to protect, serve, empower and welfare of the people. Government affairs are classified into several bagian.Lingkungan life is one of the things set out in the legislation and included in the obligatory functions organized by the local government for considering the importance of preserving the environment as a venue for human life.

Indonesia is a country with natural resources are abundant, it becomes a gift and a challenge for the state to process natural resources that exist. Indonesia's population are many and varied also become a major force in the development of the country towards prosperity. Natural products combined with human resource capabilities in the consumption process into whosoever will be great commodities that generate income for the country, both for export and local consumption. Ability in the management of natural resources for consumption should also be accompanied by the ability to manage the remnants of consumption, ie garbage management.

\footnotetext{
${ }^{1}$ Student of Masters (S2) of Law Faculty of Law Unissula Semarang and PNS in Regional Secretariat of Jepara email asmarantianita93@gmail.com
} 
In every area, especially in big cities, garbage is still a problem unsolved. Potential total rubbish/garbaged in this country had already reached the figure of 100,000 tons per day. If calculated in detail, it can be estimated that every head in Indonesia accounted for an average of $0.5 \mathrm{~kg}$ of garbage per day. ${ }^{2}$

Increasing population and an increasingly diverse human activities generate garbage production to be very large and uncontrollable. If this is not accompanied by a good management system, it will cause pollution and other environmental problems.

Jepara still has bins homework problems of large enough for local governments. Rapid population growth that intersect with the conditions of the area include a variety of coastal, lowland and hill consume influence the pattern of society so that the problem of garbage management is becoming more complex.

In Jepara, garbage management is still using the old paradigm that get garbage. Source reduction effort is expected to overcome the garbage problem, but it has not been able to run well despite being held sorting, recycling and composting. Their breakthrough in changing the paradigm of garbage management that foster self-reliance for people in garbage management consultancy based on the 3R (Reuce, Reuse, Recycle).

In addition, the government also set up a policy that aims to foster environmental awareness character within the community so that people care and are proactive in manage household garbage respectively. The policy then poured in a program called Garbage Bank.

Garbage Bank is a government effort to empower the community in garbage management as well as a forum for the community in maintaining cleanliness in a way that is beneficial to social life and economical for the Garbage Bank allow the public can save and sell the garbage.

Garbage Bank be a new breakthrough for fostering community participation in garbage management, but there are still many deficiencies that must be corrected. NII is why there needs to be an evaluation of the policies of local governments in implementing the Garbage Bank in Jepara.

Based on the description above, can be raised problems of the How to Evaluate Garbage Bank program policies?; How the public participation in the implementation of the Garbage Bank program?; What are the obstacles in the implementation of Garbage Bank?; and How does the solution in addressing the issue?

\section{Research Methods}

In this study, the research method used is descriptive qualitative research method with inductive approach. Descriptive research method is the fact finding with the proper interpretation. Descriptive research studying the problems in society as well as the procedure applicable in the community and specific situations, including about relationships, activities, attitudes, outlooks, as well as the processes that are taking place and the influence of a phenomenon ${ }^{3}$, The purpose of descriptive research is to create a

\footnotetext{
${ }^{2}$ Anonim 2008 Penanganan dan Pengelolaan Sampah Jakarta Penebar Swadaya p.1

${ }^{3}$ Ibid p. 54
} 
description, picture, or painting in a systematic, factual and accurate information on the facts and the nature of the relationship between the phenomenon investigated. ${ }^{4}$

Inductive approach is that scientific truth does not begin with a number of the underlying theory, accumulating a special experience to be common, or the concrete becomes abstract, and even later confirmed that experience into theory. ${ }^{5}$ Inductive reasoning begins by presenting statements; that has a unique scope and limited in formulating arguments that ended with the statement of a general nature. In this study, the authors tried to explain specifically the actual situation on the ground by collecting data, analyzed and then drawing conclusions from the data.

Qualitative research method is supporting a research method is based on the philosophy postpositivisme, is used to examine the condition of natural objects ${ }^{6}$, The author identifies the problems in the form of some of the facts and phenomena related to the implementation of the Garbage Bank program. Judging from the facts and phenomena are then constructed a theory that can answer the questions that cause problems in the implementation of the Garbage Bank.

As for the sources of the data in the study were as follows: Primary data is data sources provide data directly to the author; as well as secondary data is data that does not directly provide data to data collectors, for example through others or through documents. ${ }^{7}$

In this study the authors collected data through: interviews, observation. The informants interviewed were: Head of the Environment Agency, Head of Supervision and Recovery (Wasdalih), Head of Sub-field control and Conservation, Garbage Bank Organization Chairman, Society.

Observation is used to determine the actual state of the field-related issues that have been formulated. In this observation, the authors go straight to the field to evaluate the implementation of the Garbage Bank program in several District were selected as sample to determine the factors that hinder and support in the implementation of the program.

\section{Results and Discussion}

\subsection{Garbage Bank program evaluation using the model CIPP (Contect, Input, Process and Product)}

An activity referred to as a program, if such activities constitute an implementation or realization of policies that occur within a long continuous and occur within an organization involving a group of people ${ }^{8}$, Garbage Bank is an implementation of the policy based on the Ministry of Environment No. 13 of 2012 which was then elaborated in the decree on management of garbage through the Garbage Bank Regional level.

Garbage Bank categorized in a general program that lacks specificity, so the evaluation is addressed to each component which is broken down into indicators.

- Evaluation Context

\footnotetext{
${ }^{4}$ Ibid.

${ }^{5}$ Mulyadi Mohammad 2014 Metode Penelitian Praktis Kuantitatif Bandung Tarsito hp.27

${ }^{6}$ Sugiyono 2012 Sugiyono 2012 Metode Penelitian Kuantitatif Kualitatif dan R\&D Bandung Alfabeta p.9

${ }^{7}$ lbid. p.137

${ }^{8}$ Arikunto S dan Cepi S.A. J 20042004 Evaluasi Program Pendidikan Jakarta Bumu Aksara p.3
} 
Evaluation context is an attempt to describe and elaborate environment, unmet needs, populations and samples were served in the objectives of the project ${ }^{9}$,

Barbage Bank management systems, which is based on the final trash not able to effectively address the problem of garbage in Jepara regency. Landfill is no longer able to accommodate garbage progressively increasing as a result of human activities are diverse so it needs a new innovation in garbage management, one of which is the Garbage Bank.

So far the Garbage Bank in Jepara is still at the stage of education or training and recognition, achievement goals are still focused in coaching groups Garbage Bank itself, and how the Garbage Bank can have an impact on the environment.

The hope of course that formed the Office of Garbage Bank-area region can operate effectively as a place to save the trash and can develop into slaah one unit of community service and empowerment in garbage management.

- Evaluation Feedback

The purpose of the evaluation input is kemmpuan Garbage Bank in providing facilities and infrastructure, the proper officer of Bank operations and facilities to the Trash. Garbage Bank are classified into two, namely Bank Mandiri and Bank Garbage stubs.

Each Garbage Bank have different capacities to meet the completeness of infrastructure and executive employees. Based on observations made by researchers, the main infrastructure in general are met sepertio building or place transasksi, administrative books, scales and sacks. Other equipment owned by the Garbage Bank vary, for example, da Garbage Bank that already have a compost machine, sewing machines and those that do not yet have them. It is influenced by the level of finance in the provision of infrastructure and government policy in distributing aid in rotation for the Garbage Bank in Jepara district.

- Evaluation Process

CIPP process evaluation in the model refers to the "what" the activities carried out in the Garbage Bank program, "Who" designated person in charge of the program, "when" the project is implemented, while a picture can be described as follows:

- Activities undertaken in Garbage Bank program

Bank settlement Garbage is a garbage management system that apply to the Agency depositing garbage ynag amount established and agreed with the local community, to accommodate the trash who coined the economic value and savings to the amount of time, in exchange for a sum of money.

Things that become events in Garbage Bank program is how this garbage heap to less amount that is transported to landfill that the garbage management that the garbage management rely on the reduction of the source.

- The Person Appointed To Be Responsible

Garbage Bank is komuntas based program. Garbage Bank group formed by a group of people with the person in charge of garbage derived from the Bank's own masarakat designated by the community itself.

- Garbage Bank time of execution of the transaction

Garbage Bank did transactions by agreement of the group. From interviews and observations of researchers in the field, trash savings activities carried out once a

${ }^{9}$ Ibid p.29 
week. Communities have time during the week to collect garbage that has a sale value as paper, cans plastic, iron and others to later in the tube on the given day.

- Product Evaluation or results

Garbage Bank activities in addition to providing guidance on the management of garbage management through saving transactions, also provide guidance to produce recycled products and compost. Some Garbage Bank has been able to not give guidance in making products and has produced some crafts such as Pillow, bag packs of coffee, cover food, wrap wallet Rinso and others.

\subsection{Community Participation Rate}

Based on questionnaire data contained within the Environment Agency and supported by interviews conducted by the researchers to the management of Garbage Bank, the level of community participation in activities Garbage Bank program is quite good on the whole society is in a region, or a group of institutions forming Garbage Bank. Two things are a benchmark that the public welcomed the program, and feel the benefits in their daily lives, especially in keeping the environment clean.

\subsection{Obstacles to the implementation of the Garbage Bank program}

- Lack of Facilities and Infrastructure

- Lack of human resources who have the ability to manage garbage

- Lack of adequate funds

- The limited market for the products of recycling

- Lack of socialization

\subsection{Solution in the face of the constraints faced by them:}

- The Environment Agency provide relief goods to equip the facilities and infrastructure groups Garbage Bank is budgeted annually.

- Conducting training in the areas of training both management and dissemination of Garbage Bank.

- Efforts to overcome the shortage of funds is done by making the schedule turns to the group Garbage Bank granted annually.

- Opening the exhibition as a container sale early in the marketing of recycled products.

\section{Closing}

\subsection{Conclusion}

Based on observations and analysis of the Garbage Bank evaluation as a community empowerment program in garbage management Jepara as described above, it can ditari some conclusions as follows:

- CIPP model of evaluation is performed with the following results:

- Evaluation context: Garbage Bank Program in Jepara until now has been running pretty well but still at the level of public education, namely education and the introduction of more in-depth about the program as a way to manage garbage more innovative so as to further develop into a container community empowerment as to 
which it is expected that in addition to being an effort in protecting the environment.

- Evaluation of input: Infrastructures inadequate

- Evaluation Process: There are differences in the achievement of targets in the School Garbage Bank and Peoples Bank in which the Bank Garbage Garbage focuses on empowering the community while at school is more focused on education and character formation.

- Product Evaluation: Lack of market to market recycled products.

- Community participation of each group Garbage Bank has been good enough, but the scope of the district, community participation is still lacking because of the 16 new district 8 sub-districts that have a Garbage Bank. Information regarding Garbage Bank district not cover all of Jepara, especially sub-districts located in remote areas difficult to reach. It is seen from the majority of the number of Garbage Bank in Jepara regency is a region near the capital.

- Barriers faced suggest include lack of infrastructure, limited human resources who have the will to manage garbage, lack of socialization, limited funds, and the lack of markets for the products of recycling

- The solution is made to solve the problem is: to give support to the group Garbage Bank in the form of equipment to manage garbage, provide socialization, training, scheduling provision of assistance each year in rotation, providing an exhibition space for the promotion of recycled products.

\subsection{Suggestion}

- It needs a legal regulation to require every school and RT, in order to have a Garbage Bank as one of the containers of character formation in environmental management efforts.

- There needs to educate the young generation in each region, as a driving force in the development of next-generation Garbage Bank program in the community.

- Need to improve coordination and cooperation with the village government to socialize more intensively to the community, especially people in remote areas of Jepara that nurtured the motivation to form groups Garbage Bank

- Presumably in order to be improving the functions of the Garbage Bank that meet the capacity to be a parent Garbage Bank.

- The need for facilities and infrastructures landfills by type.

\section{Bibliography}

[1] Anonim 2008 Penanganan dan Pengelolaan Sampah Jakarta Penebar Swadaya

[2] Arikunto S dan Cepi S.A. J 2004 Evaluasi Program Pendidikan Jakarta Bumu Aksara.

[3] Mulyadi Mohammad 2014 Metode Penelitian Praktis Kuantitatif Bandung Tarsito.

[4] Nazir Moh. 2013. Metode Penelitian Bogor Ghalia Indonesia.

[5] Sugiyono 2012 Metode Penelitian Kuantitatif Kualitatif dan R\&D Bandung Alfabeta. 